\title{
Islamsk emirat i Gaza? Hamas vs. al-Qaida
}

FAGFELLEVURDERT

Siden valget af Hamas i 2006 er der opstået en opposition af al-Qaidainspirerede bevægelser i Gaza. Ideologiske modsætninger har ført til konflikt mellem disse grupper og Hamas. Men hvem truer hvem i denne situation? Og hvad er konsekvenserne for fredsprocessen?

Av Troels Gauslå Engell, cand.scient.pol. fra Københavns Universitet.

Hamas og al-Qaida bliver ofte skåret over én kam i de vestlige medier, som blot kalder dem militante islamister eller lignende. Det er selvfølgelig rigtigt at begge bevægelser til dels er militante islamister, hvilket sætter fokus på lighederne mellem dem. Samtidig udvisker det de grundlæggende forskelle, der er mellem bevægelsernes ideologier. Hamas er en nationalistisk og politisk organisation, mens al-Qaida ønsker en global hellig krig. Deres henholdsvis nationalistiske og globale selvforståelser og fjendebilleder adskiller ideologierne. Det samme gør deres henholdsvis brede og snævre definitioner af jihad. Denne artikel starter med at vise konfliktpotentialet mellem disse ideologiske skillelinjer.

Siden Hamas og al-Qaida er kommet i konkurrence med hinanden, har de hver især arbejdet på at mobilisere indbyggerne i Gaza til deres egen bevægelse på bekostning af den anden. Begge bevægelser forsøger at give deres ideologi tiltrækningskraft ved at overbevise palæstinenserne om, at det er deres ideologi, der bedst beskriver virkeligheden og præsenterer muligheder for et bedre alternativ. Det bliver derfor helt essentielt for dem at fremstille den politiske udvikling som værende i tråd med deres holdninger, og vise at deres løsningsforslag på palæstinensernes problemer er mest realistiske. Målet med denne artikel er at forstå Hamas og al-Qaidas versioner, for dermed at kunne se bevægelsernes rationaler og handle hensigtsmæssigt i forhold til dem.

I 1998 kunne Andrea Nüsse skrive, at der ikke var tvivl om solidariteten mellem Hamas og andre grupper, der kæmpede for en islamistisk stat i Palæstina. ${ }^{\text {I }}$ Det forhold må siges at have ændret sig siden 2006. $\mathrm{Nu}$ kritiserer al-Qaida-inspirerede grupper og Hamas eksplicit hinandens ideologier, og der opstår væbnede konfrontationer som følge af de forskellige ideologiske standpunkter.

Dette betyder ikke at ideologi er den eneste faktor der spiller ind på Hamas' og alQaidas overvejelser. Det er ligeledes relevant at se på alliancestrukturer, finansieringsmuligheder og organisatoriske forskelle. Men denne artikel fokuserer på de ideologiske forskelle og hvilken påvirkning disse har på bevægelsernes handlinger.

\section{Nation eller umma?}

Den første afgørende forskel mellem Hamas' og al-Qaidas ideologier er forståelsen af hvor solidariteten bør ligge, altså hvem der udgør det relevante fællesskab at 
forholde sig til som militant islamist. Er det nationen eller ummaen, ${ }^{2}$ forstået som globalt fællesskab for alle muslimer? Skal man enten have tilknytning til en geografisk enhed eller opfylde konfessionelle krav for at indgå i fællesskabet? Spændingen går mellem et lokalt og et globalt "os". Hamas har fokus på palæstinenserne som en begrænset gruppe. Al-Qaida mener derimod, at ummaen er det fællesskab, der skal forsvares. ${ }^{3}$

Der er dog ikke kun forskelle i fællesskabsforståelsen, men også et overlap: på den ene side inkluderer al-Qaida Hamas, da disse er muslimer. På den anden side inkluderer Hamas de al-Qaida-tilhængere, der samtidig er palæstinensere. For alQaida er hele Hamas altså en del af fællesskabet, men de repræsenterer kun en lille del. For Hamas derimod, er kun en lille del af al-Qaida med i fællesskabet. Dilemmaet er så, at bevægelserne alligevel indgår i en konkurrence med hinanden, der er eskaleret til voldelige konfrontationer.

En årsag er, at de to fællesskabsforståelser ikke anerkender hinanden. Al-Qaida mener, at ummaen opløser solidariteten i alle andre relationer. Det gælder både familie, klan, race, og ikke mindst nationen. Ligeledes gælder det for Hamas' nationalisme, at den tilsidesætter vigtigheden af trosfællesskab - samt familie, klan, race - for at lægge vægt på det nationale sammenhold. Hamas og al-Qaidas positioner er logisk uforenelige, og har modstridende interesser.

De modstridende interesser fremstår tydeligst i konteksten af en diskussion af mål og midler. For al-Qaida er Palæstinas befrielse fra zionismen kun et delmål til opnåelse af hele dar al-islams befrielse fra fremmed besættelse. Den palæstinensiske sag er samtidig et middel til rekruttering af tilhængere i resten af ummaen, fordi den tilføjer resonans til al-Qaidas ideologi. ${ }^{4}$ Omvendt er et selvstændigt Palæstina endemålet for Hamas, og ummaens rolle er at være et af midlerne til at nå dertil. ${ }^{5}$

\section{Zionister eller jøde-korsfarer-alliancen?}

Som fællesskabsforståelsen, er også Hamas' og al-Qaidas fjendebilleder forskellige, men med overlap. Begge har zionister og deres støtter som fjender; mens al-Qaida har en lang række yderligere fjender, som de til sammen kalder jøde-korsfarer-alliancen. Det væsentligste overlap er dog det mere generelle, at begge mener, at de kæmper mod besættelse af deres land. De kæmper mod undertrykkelse, og for befrielse.

Det hænger sammen med deres parallelle oprindelseshistorier, som de begge bruger som nærmest mytologiske referencer til en gylden fortid. Krigen mod Sovjetunionen i Afghanistan er for al-Qaida hvad den første Intifada er for Hamas. Det var hændelser, der fungerede som udløsende faktorer for bevægelsernes grundlæggelse, og nu fungerer de som store, legitimerende sejre at referere tilbage til.

Det er på baggrund af Hamas' og al-Qaidas beskrevne selvforståelser, at bevægelserne definerer deres fjender. Selvforståelsen fortæller hvem der skal beskyttes og hvilket område der skal befries. Fjenden er den, der truer disse. Derfor er det naturligt at al-Qaida har et bredt fjendebillede, mens Hamas kan koncentrere deres fjendskab mod zionister:

"Our message to the Israelis is this: we do not fight you because you belong to a certain faith or culture [...] Our conflict with you is not religious but political. We have no problem with 
Jews who have not attacked us - our problem is with those who came to our land, imposed themselves on us by force, destroyed our society and banished our people."

\section{Jihad som mere end hellig krig}

En tredje definerende forskel mellem Hamas og al-Qaida er måden, de bekæmper deres fjender. Begge organisationer kalder deres virke for jihad, men de lægger vidt forskelligt indhold $\mathrm{i}$ begrebet. I «Encyclopaedia of the Quran» betyder jihad som udgangspunkt bare anstrengelse, og derfor er der rum til en definitionskamp om begrebet mellem Hamas og alQaida.' Hvis man spørger al-Qaida, er jihad udelukkende lig med hellig krig. Ifølge Hamas dækker begrebet dog over alt fra væbnet modstandskamp, over kulturelle aktiviteter og undervisning, til landbrugspolitik. $^{8}$

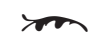

Hamas og al-Qaidas positioner er logisk uforenelige, og har modstridende interesser.

En af konsekvenserne ved de forskellige jihad-begreber bevægelserne i mellem er, at al-Qaida og Hamas indtager forskellige roller som politiske bevægelser, hvilket giver sig udslag i forskellige vægtninger af strategiske og ideologiske hensyn. Begge bevægelser tænker dog strategisk, til tider også når det er på bekostning af ideologien. En anden konsekvens af jihad-begreberne er bevægelsernes standpunkter i forhold til udnyttelse af institutionelle strukturer. Hamas bruger både de palæstinensiske strukturer - særligt efter deres overtagelse af regeringsmagten i 2006 - og en række internationale strukturer, eksempelvis når de henviser til sikkerhedsrådsresolutioner. Derimod anser al-Qaida demokratiske strukturer for at være blasfemiske, fordi de sidestiller menneskeskabte love med Guds love. FN anser de for en zionistisk organisation, og nægter derfor at have noget med dem at gøre.

\section{Al-Qaida vinder frem i Gaza 2006-2008}

Den 25. januar 2006 vandt Hamas flertal i the Palestinian Legislative Council (PLC). Siden da er der sket en fremvækst af alQaida-inspirerede grupper. ${ }^{9}$ Disse inkluderer Jaish al-Umma, Jaish al-Islam, Jaljalaat, Jund Ansar Allah, al-Suyuf al-Haq al-Islamiyah, samt adskillige flere, der ikke nævnes i denne artikel.

Selvom de ikke formelt er knyttet til alQaida, er disse gruppers ideologiske udsagn uadskillelige fra al-Qaidas, ligesom de eksplicit roser al-Qaidas ledere. Her et uddrag af den fredagsprædiken Sheikh Abu al-Nur al-Maqdisi, den senere leder af Jund Ansar Allah, holdt den i9. maj 2006:

This criminal country [USA] forgot that from among the tears and blood that they spilled throughout the years arose a new, devout pulse! A new, devout pulse that will show them the law, that has long escaped them! This new, devout pulse includes the troops of Mullah Muhammad Omar, Sheikh Osama Bin Laden, Doctor Ayman al-Zawahiri, Sheikh Abu Musab Al-Zarqawi. ${ }^{10}$

Derfor fremstår al-Qaida som en aktør på to niveauer: I) Det ideologiske, centrale lederskab omkring Osama Bin Laden og Ayman al-Zawahiri og 2) De palæstinensiske grupper, der opererer i Gaza efter 
samme ideologi som det centrale lederskab. Begge niveauer udgør dele af en større salafi-jihadistisk strømning, og denne artikel differentierer ikke mellem forskellige typer salafi-jihadisme.

De al-Qaida-inspirerede grupper i Gaza har efter deres fremkomst forsøgt at implementere deres ideologi ved at udføre så mange angreb på Israel, som de har været $\mathrm{i}$ stand til. Samtidig har de forsøgt at accelerere implementeringen af deres forståelse af sharia" ved at sprænge bomber i "umoralske" institutioner som internetcaféer og skønhedssaloner, samt ved at overfalde kvinder uden slør. I 2006-2007 var det hovedsageligt en gruppe ved navn al-Suyuf al-Haq al-Islamiyyah, der stod bag angrebene, der i en periode nåede et gennemsnit på 35 om måneden..$^{12}$ Hamas har derimod foretrukket en gradvis og dawa-styret ${ }^{13}$ overgang til sharia, hvilket harmonerer med deres tilknytning til Det muslimske broderskab. ${ }^{\text {i4 }}$

Forholdet mellem Hamas og de salafijihadistiske grupper var uproblematisk i en periode. I 2006 var der ligefrem samarbejde - eksempelvis blev Jaish al-Islams første større operation udført den 25. juni 2006 i samarbejde med militante fra Hamas. Det drejede sig om kidnapningen af den israelske soldat, Gilad Shalit. ${ }^{15}$ Den I2. marts 2007 tog de BBC-journalisten Alan Johnston til fange, hvilket skete uden Hamas' billigelse. Som modsvar arresterede Hamas den 2. juli 2007 adskillige ledende figurer $i$ Jaish al-Islam og brugte dem til at forhandle frigivelsen af Johnston. ${ }^{\mathrm{i}}{ }^{\mathrm{T}}$

Hele forløbet siden PLC-valget i 2006 foregik desuden i en kontekst af konstant og vedholdende kritik af Hamas fra Zawahiri. Parallelt med at de al-Qaida-inspirerede grupper handlede mere og mere selvs- tændigt, måtte Hamas finde sig i hård ideologisk kritik fra al-Qaidas lederskab. Kritikken gik i den periode hovedsageligt på Hamas' valgdeltagelse, samarbejdet med "sekularisterne" i Fatah, erstatningen af hellig krig med regeringsførelse, og opblødning i forhold til det historiske Palæstinas territorielle integritet. ${ }^{\text {I }}$ Zawahiri positionerer på den måde al-Qaida som en mere principfast bevægelse i kampen mod besættelsesmagten og for en islamistisk stat. Han udfylder således det ideologiske vakuum, Hamas efterlod, da de indgik i det parlamentariske spil og dermed accelererede en igangværende ideologisk opblødning. ${ }^{18}$

Parallellen til Hamas' kritik af Fatah i Oslo-perioden er slående. Ligesom Hamas gjorde i I99oerne, ${ }^{19}$ beskriver al-Qaida sig selv som den bevægelse, der opretholder modstandskampen principfast, og ikke sælger ud af palæstinensernes land og rettigheder.

\section{Gaza-krigens påvirkning}

Alligevel valgte Hamas at indgå en våbenhvile med Israel den I9. juni 2008 og med et halvt års varighed til den I9. december 2008..$^{2 \circ}$ Det gav ekstra belæg til Bin Ladens og Zawahiris påstande om, at Hamas tilsidesætter den væbnede jihad, og det varede da heller ikke længe før spændingerne mellem Hamas og de al-Qaida-inspirerede grupper steg.

Derfor havde Hamas ved udløbet af våbenhvilen med Israel behov for at modgå al-Qaidas kritik, om at de havde opgivet den væbnede jihad. Det var en af grundene til at de ikke forlængede våbenhvilen. Den ideologiske positionskamp med al-Qaida bidrog således til at gøre det rationelt for Hamas at revurdere sin strategi, som i en 
lang periode havde været at vise, at de kunne holde fred, for dermed at opnå international anerkendelse. Det nye var, at Hamas' ledelse ud fra deres perspektiv vurderede, at fordelen ved at imødekomme alQaidas kritik var større end ulempen ved at risikere israelske angreb og at få et dårligere forhold til Vesten. At Israel selv havde brudt våbenhvilen i perioden inden, må antages at have sænket våbenhvilens værdi i Hamas' vurdering, hvilket gjorde beslutningen mere sandsynlig, selv hvis al-Qaida ikke havde været til stede. Episoden peger ikke desto mindre på, at al-Qaidas propaganda for det første blev anset for en større trussel end tidligere. Og for det andet at den politiske gevinst ved våbenhvilen havde været utilstrækkelig til at fastholde Hamas på fredssporet; fx mente Hamas ikke at isoleringen af Gaza var blevet lempet, sådan som det var aftalen med Israel at den skulle.

I Gaza-krigens sidste dage skete der en væsentlig diplomatisk udvikling, da lederen af Hamas' politbureau, Khaled Meshaal, blev inviteret til en konference i Doha. ${ }^{2 \pi}$ Invitationen var på samme niveau som invitationen til PA-præsident Mahmoud Abbas. Denne nægtede at komme, når Hamas var inviteret på samme vis som ham, fordi han fastholdt, at PLO er den eneste legitime repræsentant for det palæstinensiske folk. På grund af det daværende fokus på Gazakrigen, opnåede Hamas rollen som repræsentant for palæstinenserne. Denne nye legitimitet, som i høj grad byggede på Hamas' rolle som aktivt i kamp med den israelske hær, kan ikke overvurderes.

I krigens efterspil fortsatte al-Qaida sine hyppige kommentarer til palæstinensisk politik. De udtrykte blandt andet medfølel- se og respekt for palæstinensernes tab. Og hvor al-Qaida under krigen ikke kritiserede Hamas, kom der efter krigen en række indirekte kritikpunkter frem, som da Zawahiri spørger til hvordan jihad kan begrænses til Palæstina, eller da Bin Laden afviser nytten af "calming agreements". ${ }^{22}$

\section{Det islamiske emirat i Gaza}

Sommeren 2009 så en intensivering af de al-Qaida-inspirerede gruppers angreb på israelske og vestlige mål. Det var altså som kulminationen på den hidtil mest seriøse bølge af angreb, at Jund Ansar Allah den I4. august 2009 udråbte det islamiske emirat i Gaza fra Ibn Taymiyyah-moskéen i Rafah. Lederen af Jund Ansar Allah var den

Den 14. august 2009 udråbte Jund Ansar Allah det islamske emirat i Gaza. Hamas angreb moskeen.

samme Abu al-Nur al-Maqdisi, som er citeret ovenfor for sin støtte til al-Qaida. Gruppens militante udgav et dokument med deres loyalitetserklæring til det nye emirat og dets leder, hvori de blandt andet annoncerede, at de ville samle deres militære strukturer og bede alle muslimer i Gaza om at støtte dem. ${ }^{23}$

Det kunne Hamas ikke lade stå uimodsagt. De angreb moskéen, hvor cirka ıoo militante fra Jund Ansar Allah var samlet. I den timelange ildkamp blev 26 mennesker dræbt, herunder seks Hamas-militante og Abu al-Nur al-Maqdisi. De øvrige militante i moskéen blev arresteret. ${ }^{24}$

Den I6. august udgav Jund Ansar Allah deres kommentar til angrebet. Først og 
fremmest truer de med hævn mod Hamas. De siger derudover, at Hamas startede konflikten; at de ikke ønsker intra-palæstinensisk konflikt; at de ikke kalder andre muslimer for vantro; at Hamas må have været bange for dem, selv om flere af deres militante har bånd til Hamas-folk, siden de angreb så voldsomt; at demokrati og valg ikke egner sig for ægte mujahidin, altså de der udfører jihad. ${ }^{25}$

Hamas havde på sin side argumenteret for nødvendigheden af aktionen med I) at udråbelsen af et emirat var en udfordring af deres legitime voldsmonopol, og dermed en underminering af sikkerhedssituationen i Gaza. 2) At Jund Ansar Allah består af afvigere, som misfortolker islam. 3) At de har dårlig indflydelse på ungdommen og vildleder dem. ${ }^{26}$

Et tegn på hvor alvorligt konflikten mellem Hamas og Jund Ansar Allah skal tages, kan læses af den martyr-erklæring Hamas udsendte den I7. august. Det drejer sig om de seks dræbte Hamas-folk og særligt lederen Muhammad Jabril Shamali. I erklæringen anses Hamas-folkene for martyrer, og hele episoden skrives ind i kontekst af Intifadaen og kampen mod besættelsen. På den måde bliver det en indirekte udskilning af Jund Ansar Allah-militante fra det palæstinensiske fællesskab. ${ }^{27}$

Men efter at have forsvaret sig mod beskyldningerne, giver Jund Ansar Allah tilbage med kritik. Ligesom Hamas er tæt på at udskille Jund Ansar Allah fra det palæstinensiske fællesskab, kommer de tæt på at kalde Hamas for frafaldne, når de gentager al-Maqdisis beskrivelse:

Because it [Hamas] has accepted to be a secular and democratic government in Shariah and method, imparted legitimacy to it, and confused the followers and legislated laws that Allah the Great and Almighty did not permit, then we say what Abu Bakr al-Siddiq, may Allah be pleased with him, said in the sermon of his ascension to the throne of the Caliphate: Obey me as long as I obey Allah in you [sic] and in His messenger. If I disobey Him, then you do not have to obey me. ${ }^{28}$

De siger, at Hamas ikke regerer efter Guds love, og at man ikke skal adlyde en regering, der ikke følger Guds love. Alligevel tager de ikke skridtet og ekskommunikerer Hamas. Men Jund Ansar Allah står ikke alene med kritikken af Hamas. De bakkes op af andre al-Qaida-inspirerede grupper i Palæstina samt al-Qaidas regionale organisationer, som endda formulerer sig i stærkere vendinger end Jund Ansar Allah selv. ${ }^{29}$

\section{Al-Qaida som trussel mod Hamas}

I slutningen af 2009 og starten af 2010 er al-Qaidas fokus på Palæstina stærkere end nogensinde før. Zawahiri dedikerede i december 2009 størstedelen af en tale til kritik af Fatah. I) For ikke at kæmpe for en islamistisk stat og 2) for endda at have forrådt den nationalistiske befrielseskamp, som det ellers er Fatahs rolle at være den institutionelle manifestation af. ${ }^{\circ}$ Og den 24. januar 2010 udgav Bin Laden en kort tale, hvis hovedpointe var, at USA ikke vil få fred, før befolkningen i Gaza gør..$^{3^{1}}$ Dette stærke fokus kan blandt andet indikere, at det centrale al-Qaida-lederskab ønsker fortsat vækst blandt palæstinenserne.

Fordi Gaza stadig er isoleret, og fordi Fatah ikke får tilstrækkelige diplomatiske sejre på Vestbredden, virker al-Qaidas ideologi mere og mere som den, der bedst beskriver virkeligheden som set fra Gaza. Jeg bygger her på samme antagelse som 
International Crisis Group om at mistillid til fredsprocessen, en forværret humanitær situation og civile tab er befordrende for radikale holdninger. ${ }^{32}$ Eksempelvis mener 27,9 procent af befolkningen i Gaza, at palæstinensernes mål er at erobre Israel og udslette den jødiske befolkning, mens yderligere 22,I procent mener, at målet er at genskabe det historiske Palæstina under arabisk styre med magt. ${ }^{33}$

Hverken Fatahs samarbejde med besættelsesmagten eller Hamas' forsøg på forhandlinger og unilaterale våbenhviler har opnået resultater, som palæstinenserne er tilfredse med. I Gaza var det således kun 26,2 procent der i december 2009 mente, at man skulle genoptage forhandlinger med Israel i den daværende situation. ${ }^{34}$

De nævnte holdninger står al-Qaida fast på, mens både Hamas og Fatah udtrykker sig mere blandet. Derfor opstår der en diskrepans mellem Hamas', Fatahs og befolkningen i Gazas opfattelse af deres politiske situation. Dette er med til at gøre det mere rationelt for befolkningen at søge væk fra disse bevægelser og mod mere radikale, ofte al-Qaida-inspirerede bevægelser. For Hamas-folk er en gruppe som Jaljalaat et oplagt eksempel, da den hovedsageligt består af militante med erfaring fra Hamas. ${ }^{35}$

For at modgå denne bevægelse af folk der flytter til al-Qaida, er Hamas begyndt at ændre deres politikker i retning af al-Qaidas præferencer. Der kan være andre grunde til at Hamas ændrer sin politiske linje, men ud fra denne artikels fokus på ideologi, fremstår kampen med al-Qaida som en central begrundelse. Hvor Hamas' valgplatform på det nærmeste ikke havde islamiserende elementer, ${ }^{36}$ ser man nu et stigende antal regler og institutioner til at gennemtvinge islamistiske sharia-fortolkninger. Først blev sløret et socialt pres, siden blev det gjort påkrævet i skolerne og for kvindelige dommere. Det er ikke længere tilladt kvinder at more sig ved badning, ligesom berøring på stranden er forbudt. Og til at håndhæve disse politikker, har Hamas oprettet et moralpoliti. Moralpolitiet har ligeledes forsøgt at stoppe kvinder $i$ at ryge vandpibe, samt salg af jeans, musik og film. ${ }^{37}$

På grund af Hamas' helt konkrete problem $i$ at de mister militante til al-Qaidainspirerede bevægelser, kan tilsidesættelse af den væbnede modstandskamp vise sig at blive kostbar, så længe forhandlinger fremstår nyttesløse. Fx vil en aftale om en længere våbenhvile med Israel, eller en opfattet overgivelse til Fatah gennem en underordnet position i en samlingsregering, ikke harmonere med de af Hamas' medlemmer, som ideologisk er tættest på al-Qaida og som derfor er mest tilbøjelige til at skifte deres loyalitet. Opblødning af modstandskampen vil også være belæg for Jund Ansar Allah og de øvrige salafi-jihadistiske gruppers kritik af Hamas, som hidtil er stoppet lige inden ekskommunikation. Det kan derfor risikere at føre til, at Jund Ansar Allah tager skridtet og ekskommunikerer Hamas. I så fald vil resultatet være en voldsom optrapning af konfrontationerne bevægelserne imellem.

Ud fra ovenstående er det sandsynliggjort at kalkulen har ændret sig: al-Qaidafolkene er blevet en tilstrækkelig stor ideologisk trussel, til at Hamas vurderer, at det bedre kan betale sig at tilpasse sig al-Qaidatendenser i samfundet end at nærme sig

Palestinske Hamas-tilhengere protesterer mot Israels plan om å inkludere to steder på Vestbredden i deres nasjonarvliste. 
babylon15:babylon5 24.03 .1014 .50 Page 85 -
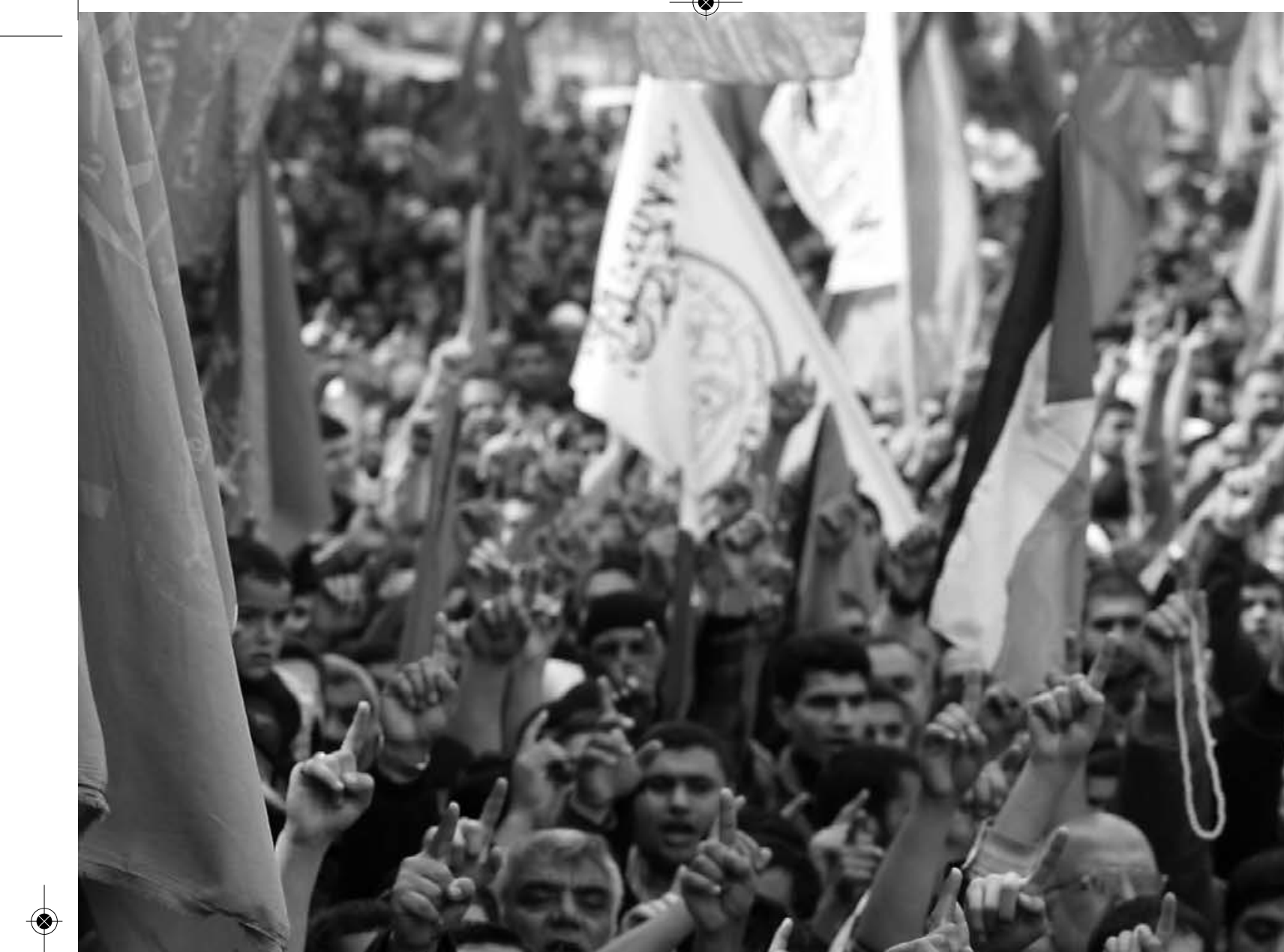

wat 5 ?

Sif हne

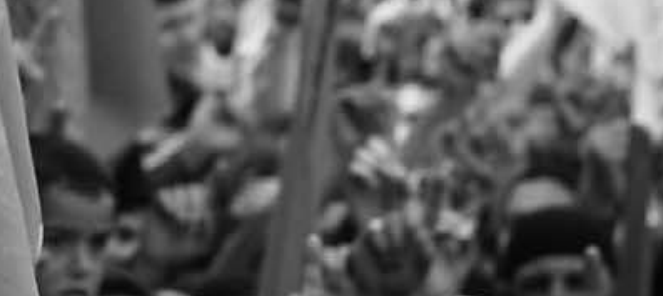

noy

Tingers 4

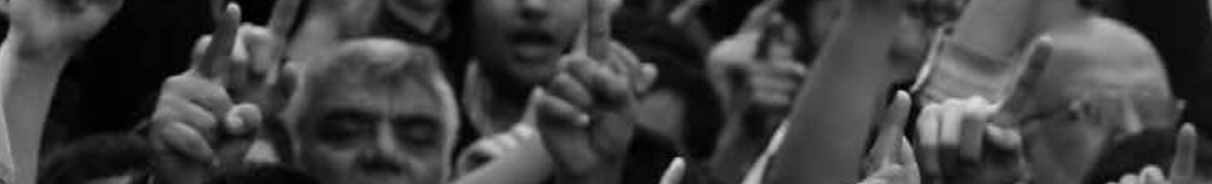

(1)

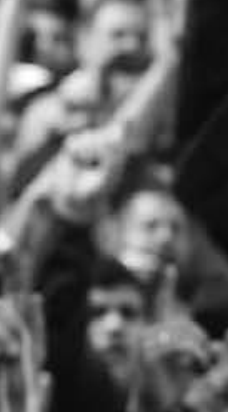

y

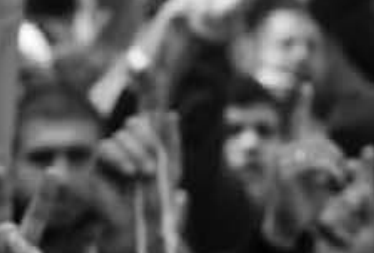

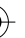

Q.

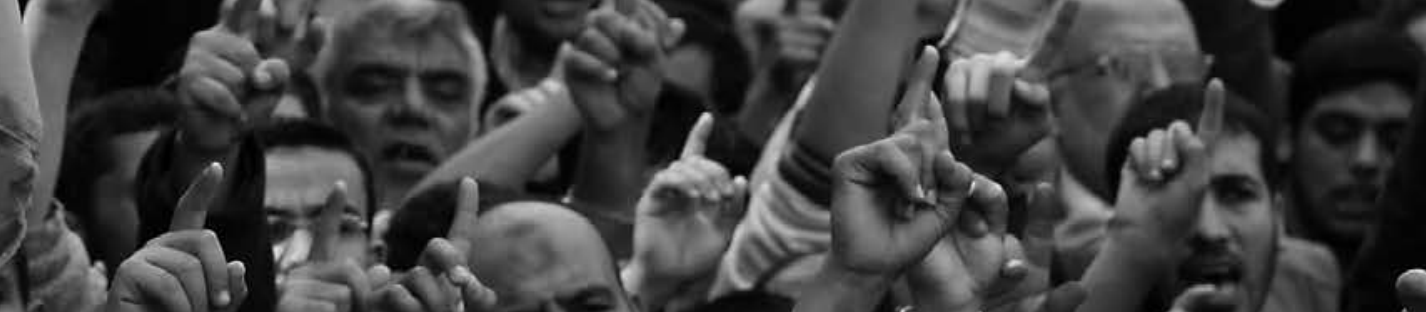

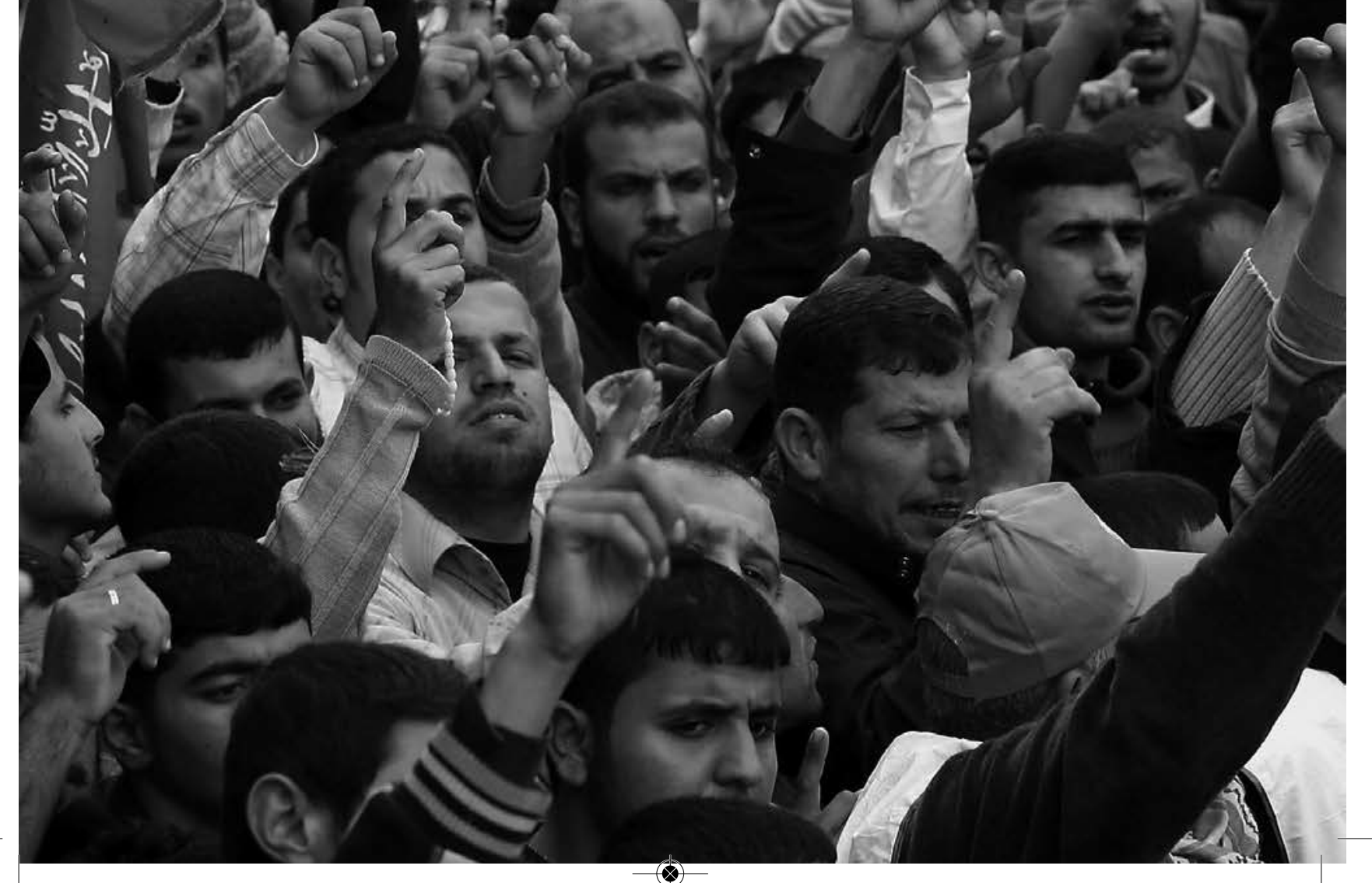


sekulære aktører, fx i Fatah og Vesten. Derfor fremskynder de implementering af islamistiske regler. Som allerede nævnt var samme ideologiske pres medvirkende til at Hamas i december 2008 vurderede, at de ikke ville forny våbenhvilen med Israel, hvilket blot bekræfter billedet.

\section{Hamas' fortsatte dominans}

Inden al-Qaida blev en aktør i Gaza kunne de ikke trues - det er først nu, hvor de er etablerede, at de har noget at miste. Der er derfor en række forhold, der kan nuancere vurderingen af hvem der truer hvem.

Først og fremmest er Hamas stadig den helt dominerende islamistiske bevægelse i Gaza. Den stigende trussel fra al-Qaidainspirerede bevægelser er endnu langt fra at kunne vinde et militært opgør. Jund Ansar Allah var således altfor tidligt ude med udråbelsen af et emirat $i$ forhold til niveauet af deres organisatoriske opbygning, og de holdt kun stand få timer mod Hamas' styrker.

Uanset hvem der vinder definitionen af episoden med det islamiske emirat, kan det militære nederlag have negative konsekvenser for Jund Ansar Allahs betydning, fordi de fremstår som mindre egnede end Hamas. Og Hamas kan bruge sin rolle som ordensmagt til at fremstille episoden som nødvendig for palæstinensisk enhed og stabilitet. Hvis det lykkes, vil episoden have været en strategisk og ideologisk sejr for Hamas.

Al-Qaida viser desuden endnu en høj grad af forsigtighed i forholdet til Hamas. Siden 2006 har det centrale al-Qaida-lederskab blandet sig direkte i palæstinensisk politik og kritiseret Hamas. Der er dog stadig nogle røde linjer de ikke tør overtræde. Fx har Zawahiri efter Hamas' magtoverta- gelse i 2007 måttet differentiere sin kritik til kun at gælde Hamas' lederskab og ikke de almindelige medlemmer. Og siden Gaza-krigen er den direkte kritik helt forstummet fra Bin Laden og Zawahiri. ${ }^{38}$ Senest i talen fra december 2009 dækker Zawahiris kritik kun Fatah. Ligesom Bin Ladens tale i januar 2oro kun handler om at støtte palæstinenserne, og hverken kritiserer Hamas eller Fatah.

Det hænger sandsynligvis sammen med den øgede opbakning Hamas vandt blandt regionens befolkninger, fordi de aktivt bekæmpede besættelsesmagten. For når Hamas vinder popularitet i regionen, bliver det strategisk uhensigtsmæssigt at konfrontere dem ideologisk. Den nyvundne popularitet udmøntede sig i tildelingen af status som palæstinensernes officielle repræsentant i Doha.

I modsætning til al-Qaida, har Hamas opretholdt og skærpet sin kritik. Sammen med de militære operationer mod al-Qaidainspirerede grupper tyder det på, at Hamas måske nok ser en ideologisk trussel, der er ved at udvikle sig til en mobiliseringstrussel, men at de endnu ikke frygter al-Qaidas operationelle styrke i Gaza.

Fremtiden vil vise om al-qaidaseringen af Gaza fortsætter, eller om Hamas formår at dæmme op for den. Hvis Hamas opnår politiske resultater fra Fatah eller Israel, vil det styrke dem imod salafi-jihadisterne. Hvis de ikke opnår resultater, vil de alQaida-inspirerede grupper derimod nemt kunne argumentere for, at Hamas' forsøg på forhandlinger og våbenhviler ikke nytter.

\section{Konsekvenser for fredsprocessen}

Den nye situation, hvor al-Qaida-inspirerede grupper er tilføjet listen over aktører i 
Gaza, komplicerer fredsprocessen yderligere. Hamas er nu nødsaget til at vægte hensynet til al-Qaida-tendenser blandt palæstinenserne over for hensynet til Fatah, Israel, vestlige aktører et cetera. På den måde bliver Hamas' omkostninger ved et eventuelt samarbejde med disse forhøjet. I en forhandling med Fatah eller Israel - fx om en fornyet national samlingsregering eller om våbenhvile - bliver Hamas derfor nødt til at kræve større resultater end hidtil, for at kompensere for at de åbner sig for ideologisk kritik fra al-Qaida. Det kan medvirke til at besværliggøre dannelsen af en ny samlingsregering, der gennem politisk inklusion sandsynligvis ville have en modererende virkning på Hamas' ideologi, og som ville kunne agere som en reel partner i fredsforhandlinger. 39

Det skal med andre ord kunne betale sig for den politiske del af Hamas at svække deres legitimitet blandt deres mere radikale sympatisører, hvis de skal være interesserede i forhandlinger. Hvis ikke Hamas kan hjembringe tilstrækkelige resultater gennem politisk arbejde, vil det virke mere rationelt ud fra deres synsvinkel at imødekomme al-Qaida-kritikken.

At Hamas kalibrerer sine politikker i retning af al-Qaidas kan have mange årsager. Men ud fra denne artikels ideologi-perspektiv, fremstår en af årsagerne som værende et forsøg på at vende al-qaidaseringen af Gaza. Fordi de har prøvet at håndhæve en våbenhvile uden at få resultater ud af det og befolkningen ikke foretrækker en forhandlingsløsning i den nuværende situation, er der ideologisk resonans i at skærpe den konfrontatoriske kurs. De to strategier de kan vælge til dette formål - deres ideologi taget i betragtning - er først og fremmest, at de kan optrappe konflikten med Israel, hvilket vil underminere belægget for argumentet om, at de ikke repræsenterer væbnet jihad. Alternativt kan de accelerere implementeringen af et islamistisk governance-ideal. Vi har set politikker, der kan analyseres som eksempler på begge strategier, herunder at Hamas i december 2008 ikke fornyede våbenhvilen med Israel, og at de har oprettet et moralpoliti.

Så når Hamas i en forhandlingssituation med Israel eller Fatah stiller krav, bør disse og vestlige aktører inddrage det forhold i deres kalkuler, at Hamas står til at tabe terræn til al-Qaida, hvis de ikke hjembringer resultater. Beslutningstagere må på den baggrund gøre sig klart, om de ønsker, at deres politikker skal tilgodese enten Hamas' eller al-Qaidas ideologiske tiltrækningskraft og dermed mobiliseringspotentiale. Kun politikker der svækker det samlede islamistiske felt kommer ud over dette dilemma. Vestlige og israelske aktører må med andre ord gøre sig klart, at deres politikker indgår som brikker i et ideologisk positioneringsspil i Palæstina.

\section{Konklusion}

Hamas og al-Qaida repræsenterer hver deres islamistiske ideologi, som er gensidigt udelukkende. Samtidig er tilstedeværelsen af Al-Qaida-inspirerede bevægelser nu et faktum i Gaza. Det har ført til en ideologisk konfrontation mellem de to bevægelser. Denne konfrontation har udviklet sig siden 2006 og er eskaleret til voldelige sammenstød.

Som vi har set, går tendensen i Gaza mod en større grad af orientering mod alQaidas ideologiske standpunkter. Både ved at Hamas mister støtte og militante til de mere ekstreme grupper, og ved at de tilpas- 
ser deres politikker til al-Qaidas salafi-jihadisme.

Dette er med til at forklare, hvorfor Hamas ikke ville forlænge våbenhvilen med Israel i december 2008, hvorefter Israel svarede med Gaza-krigen. Det er også med til at forklare, at Hamas er begyndt at institutionalisere en islamistisk sharia-fortolkning, fx gennem oprettelsen af et moralpoliti til at overvåge skærpede regler.

Denne udvikling komplicerer fredsprocessen mere end den allerede var. Det viser nemlig, at Hamas mener, at de under visse omstændigheder får mere ud af at tilpasse sig al-Qaidas ideologiske linje end Fatahs forhandlingsspor. Fra Hamas' vinkel skal truslen fra al-Qaida altså vejes over for omkostningerne ved fortsat isolering fra vestlige donormidler, samt splittelsen mellem Gaza og Vestbredden. Vestlige beslutningstagere bør tage dette forhold med i deres vurderinger, når de formulerer deres strategi for at opnå den forsoning mellem Hamas og Fatah, der er nødvendig for at fredsprocessen kan skride fremad.

Mønsteret i de militære konfrontationer mellem Hamas og salafi-jihadisterne tyder desuden på, at de al-Qaida-inspirerede grupper vokser sig større og stærkere. De er endnu på et niveau, hvor Hamas kan håndtere dem. Men selv om Hamas er overlegne, er magtbalancen ved at forrykke sig. Tidligere kunne Hamas håndtere forholdet til salafi-jihadisterne uden vold. Nu skal der vold til for at holde dem nede, sådan som vi har set med udråbelsen af det islamiske emirat i Gaza. Hvis situationen fortsætter uforandret, vil de med tiden kunne repræsentere en virkelig seriøs udfordring for Hamas.

Samtidig har Hamas vist sig i stand til styrke deres egen ideologiske position. Fx ved at vende Gaza-krigen til en diplomatisk sejr, som fik det centrale al-Qaida-lederskab til at moderere sin kritik, fordi Hamas fremstod som relevante i befolkningens opfattelse. Lykkes det ligeledes Hamas at fremstille deres angreb på Jund Ansar Allah som nødvendig for at opretholde ro og orden i modsætning til at splitte palæstinenserne yderligere, vil det give dem fornyet troværdighed. Og hvis Hamas hjembringer politiske resultater som følge af forhandlinger eller en våbenhvile, vil al-Qaidas ideologi miste tiltrækningskraft.

$$
\cdot f \cdot
$$

I Nüsse, Andrea: «Muslim Palestine - the ideology of Hamas. Amsterdam: Harwood Academic Publishers, I998, s. 96.

2 Denny, Frederick: “The meaning of 'Ummah' in the Qur'an", i History of Religions, vol. I5, nummer I, 1975.

3 Lawrence, Bruce: «Messages to the world: The statements of Osama Bin Laden». London: Verso, 2005 Ss. 7I; IIg; I5I.

4 Zawahiri, Ayman al-: "Knights under the Prophet's banner", i Mansfield, Laura: «His Own Words». USA: TLG Publications, 2006, s. 2II.

5 Hamas: “The Hamas Charter", i Hroub, Khaled: «Hamas - political thought and practice». Washington: Institute for Palestine Studies, 2000, artikel I4.

6 Meshaal, Khaled: "We will not sell our people or principles for foreign aid", i Tamimi, Azzam: «Hamas - unwritten chapters». London: Hurst \& Company, 2007, s. 267-8.

7 Landau-Tasseron, Ella: “Jihad" i Jane Dammen McAuliffe (red.): «Encyclopaedia of the Quran». Washington: Georgetown University, 2009, Brill Online.

8 Se Hamas' valgplatform fra 2006 i Tamimi, Azzam: «Hamas: unwritten chapters». London: Hurst \& Company, 2007.

9 Hovdenak, Are: «Al-Qaida - a challenge for Hamas». Oslo: Forsvarets Forskningsinstitutt, 2009.

Io Hovdenak, Are: «Al-Qaida - a challenge for Hamas». Oslo: Forsvarets Forskningsinstitutt, 2009. Side 24.

II Calder, N.: "Sharia", i P. Bearman, Th. Bianquis, C.E. Bosworth, E. van Donzel og W.P. Heinrichs (red.): «Encyclopaedia of Islam, Second Edition, Brill Online, zoro.

I2 "To compare Hamas with al-Qaeda is both illogical and 
baseless", Ikhwanweb v. Saleh al-Naami, I8. juli 2007, http://www.ikhwanweb.com/article.php?id=1002 (08.02.10)

I3 Canard, M.: “Da'wa”, i P. Bearman, Th. Bianquis, C.E. Bosworth, E. van Donzel og W.P. Heinrichs (red.): «Encyclopaedia of Islam, Second Edition, Brill Online, 20 Iо.

I4 Hamas: "The Hamas Charter", i Hroub, Khaled: «Hamas - political thought and practice». Washington: Institute for Palestine Studies, 2000, artikel 2.

I5 Hovdenak, Are: «Al-Qaida - a challenge for Hamas». Oslo: Forsvarets Forskningsinstitutt, 2009. Side 28.

I6 "Timeline: Alan Johnston Abduction", BBC, http://news. bbc.co.uk/2/hi/middle_east/65I8873.stm (08.02.I0)

I7 Zawahiri, Ayman al-: taler udgivet 4. marts 2006; 9. juni 2006; 20. december 2006; II. marts 2007; 6. maj 2007.

I8 Hroub, Khaled: "A 'new Hamas' through its new documents", i Journal of Palestine Studies, vol. 35, nummer I, 2006, s. 6-20.

I9 Mishal, Shaul \& Avraham Sela: «The Palestinian Hamas: Vision, violence, and coexistence». New York: Columbia University Press, 2006, s. 42

20 "The Jaljalaat phenomenon in the Gaza Strip", Israeli Security Agency, http://www.shabak.gov.il/English/En TerrorData/Reviews/Pages/Jaljalat_en.aspx (08.02.10)

2I "Same tactics apply", Al-Ahram Weekly v. Ezzat, Dina, 22. 28. januar 2009 , http://weekly.ahram.org.eg/2009/ 931/egr.htm (08.02.I0)

22 "Al-Zawahiri: 'The sacrifices of Gaza and the plotting against it", Zawahiri, Ayman al-, 3. februar 2009, http:// www.nefafoundation.org/miscellaneous/FeaturedDocs/ nefazawahirio209.pdf (08.02.I0); "Usama Bin Laden: "Practical steps to liberate Palestine'”, Bin Laden, Osama, I4. marts 2009, http://www.nefafoundation.org/miscella neous/FeaturedDocs/nefaublo309.pdf (08.02.I0)

23 "Jund Ansar Allah declares "Islamic Emirate" in Gaza", Jund Ansar Allah, I4. August 2009, http://www.nefa foundation.org/miscellaneous/nefa_jundansarallaho 8I409.pdf (08.02.I0)

24 "Hamas: Head of Al-Qaida affiliate killed in Gaza", Haaretz Online v. Avi Issacharoff, I5. august 2009, http://www.haaretz.com/hasen/spages/IIo7639.html (08.02.10)

25 "Jund Ansar Allah threatens 'response' to Hamas clashes", Jund Ansar Allah, I6. august 2009, http://www. nefafoundation.org/miscellaneous/FeaturedDocs / nefa_jundansarallaho81609.pdf (08.02.I0)

26 "Hamas branded 'too secular", Al-Ahram Weekly v. Saleh al-Naami, 20-26. august 2009, http://weekly.ahram. org.eg/2009/96I/rer.htm (08.02.I0)

27 "Al-Qassam Brigades mourns 'martyrdom' of comrades", Hamas, I7. august 2009, http://www.nefafoundation. org/miscellaneous/nefa_alqassamo8I709.pdf (02.08.IO)

28 "Jund Ansar Allah clarifies Rafah events", Jund Ansar Allah, 24. august 2009. Oversat af SITE Institute.
29 "AQIM condemns Hamas for Rafah events", Al-Qaida i Islamisk Maghreb. Oversat af SITE Intelligence Group.

30 Kurz, Anat: "Fatah and the politics of violence". Brighton: Sussex Academic Press, 2005, s. I52

3I "Dr. Ayman al-Zawahiri: 'Idol of National the Unity', Zawahiri, Ayman al-, I2. desember 2009, http://www. nefafoundation.org/miscellaneous/nefaZawahiriızo9 .pdf (o8.02.Io); "Usama Bin Laden: 'From Usama to Obama", Bin Laden, Osama, 24. januar 20IO, http:// www.nefafoundation.org/miscellaneous/UBLoiıo.pdf (08.02.10)

32 "Ruling Palestine I: Gaza under Hamas", International Crisis Group. Middle East Report no 73,19. marts 2008, http://www.crisisgroup.org/home/index.cfm?l=I\&id $=5525$ (07.03.10)

33 "Palestinian public opinion poll no (34)", Palestinian Center for Policy and Survey Research, 24. desember 2009 http://www.pcpsr.org/survey/polls/2009/p34e.html\# main (04.03.10)

34 "Palestinian public opinion poll no (34)", Palestinian Center for Policy and Survey Research, 24. desember 2009 http://www.pcpsr.org/survey/polls/2009/p34e.html \#main (04.03.10)

35 "The Jaljalaat phenomenon in the Gaza Strip", Israeli Security Agency, http://www.shabak.gov.il/English/En TerrorData/Reviews/Pages/Jaljalat_en.aspx (08.02.Io)

36 Hroub, Khaled: "A 'new Hamas' through its new documents", i Journal of Palestine Studies, vol. 35, nummer I, 2006, s. 6-20.

37 "Hamas Fights Over Gaza's Islamist Identity", New York Times v. Khodary, Taghreed al- \& Ethan Bronner, 5. september 2009, http://www.nytimes.com/2009/09/06/ world/middleeast/o6gaza.html?_r=I (02.08.Io); "Hamas bans women from motorcycles”, Jerusalem Post v. Associated Press, 7. oktober 2009, http://www.jpost.com/ servlet $/$ Satellite cid $=\mathrm{I} 25486 \mathrm{I} 889804$ \& pagename $=$ JPost\%2FJPArticle\%2FShowFull (08.02.I0); "Hamas Leaders Enforce Sharia Law in Gaza Strip”, CBN News, I7. august 2009, http://www.cbn.com/cbnnews/world/ 2009 /August/Hamas-Leaders-Enforce-Sharia-Law-inGaza-Strip/ (08.02.10)

38 "Usama Bin Laden: 'Statement to the American people', Bin Laden, Osama, I3. september 2009, http://www.nefa foundation.org/miscellaneous/nefaublog०9.pdf (08.02.10)

39 Gunning, Jeroen: "Peace with Hamas? The transforming potential of political participation", i International Affairs, vol. 8o, nummer 2, 2004, s. 233-255; Hovdenak, Are: "Hamas in transition: The failure of sanctions", i Democratization, vol. I6, nummer I, 2009, s. 59-80. 